\title{
Constitutional stability in japan not due to popular approval
}

\author{
Satoshi Yokodaido
}

(Received 17 December 2018; accepted 20 January 2019)

\begin{abstract}
The Japanese Constitution has never experienced any amendment since its enactment in 1947. This article claims that the reason is not the Japanese people's support of it from the heart. The hypothesis presented in this article is that many other political, structural and cultural reasons have gradually deprived the Constitution's normative force among people, and have made constitutional amendment unnecessary in Japanese politics.
\end{abstract}

Keywords: Japanese Constitution; Goken-ha and Kaiken-ha; constitutional stability; constitutional amendment

\section{A. Introduction}

According to the large-scale statistical research conducted on constitutions throughout the world since 1789 , the average life expectancy of a constitution is 17 years, ${ }^{1}$ and the median length is 19 years. $^{2}$ Moreover, the longevity of Constitutions enacted during a foreign occupation is generally short. ${ }^{3}$ Nevertheless, the Japanese Constitution has remained unamended since it was promulgated on November 3, 1946, and enacted under occupation on May 3, 1947, all while. It is the oldest unamended constitution in the world. ${ }^{4}$

Why is the Japanese Constitution so stable? What factors influence that stability? It is sometimes said that the stability is due to the Japanese people's sincere endorsement of the Constitution. Yet, the Liberal Democratic Party (LDP) — which has endorsed revision of Constitution since its founding has been the ruling party for almost the entire post-war era. Moreover, a recent study of opinion polls concerning the Constitution of Japan since World War II found that the people do not see the Constitution as something so sacred that it should never be amended. ${ }^{5}$ Therefore, the conventional explanation for Japan's constitutional stability appears incorrect or inadequate.

Given that there is always a majority in favor of the constitutional amendment, why is the Japanese Constitution still intact? This fact forces us to reconsider the relationship between constitutional stability and popular approval. This Article advances mutually related reasons for why the Japanese Constitution has not been amended: Post-War politics, the structure of the

\footnotetext{
${ }^{*}$ Satoshi Yokodaido is a Professor of Constitutional Law, Keio University Law School. The author is grateful to Prof. Oran Doyle for his suggestive comment on my early draft.

${ }^{1}$ Zachary Elkins, Tom Ginsburg \& James Melton, The Lifespan of Written Constitutions, Record OnLINE, http://www.law. uchicago.edu/alumni/magazine/lifespan.

${ }^{2}$ Zachary Elkins, Tom Ginsburg \& James Melton, The Endurance of National Constitutions 129-30 (2009).

${ }^{3}$ Zachary Elkins, Tom Ginsburg \& James Melton, Baghdad, Tokyo, Kabul . . . : Constitution Making in Occupied States, 49 WM. \& MARY L. REV. 1139, 1153-58 (2008).

${ }^{4}$ See Constitution Rankings, Comparative Constitutions Project, http://comparativeconstitutionsproject.org/ccp-rankings/.

${ }^{5}$ See infra Section B.II.
} 
Constitution, judicial restraint on constitutional issues, and an evaluation of the necessity of constitutional amendments. All of these factors create a culture that treats the Constitution as unamendable or irrelevant.

Section B briefly covers the two conventional dichotomous attitudes toward the Constitution in Japan and surveys their analysis of the stability of the Constitution. The shortcomings of these analyses will also be pointed out. Based on that recognition, Section $\mathrm{C}$ discusses the need to focus on other factors to understand the Japanese Constitution's lack of change. Section C demonstrates the problems with the two conventional attitudes toward the Constitution in Japan. Section D surveys post-war politics, focusing on the peace clause in Article 9. Japan created the Self-Defense Forces (SDF) - a military-like entity-without any constitutional amendment in the early stages of the post-war period. This affected people's attitudes to the Constitution and Constitutional amendments. Next, Section E focuses on the structural characteristics of the Japanese Constitution, which leave plenty of room for interpretation and allowed post-war politics to develop without any constitutional amendments, as discussed in Section D. Section E treats judicial review in Japan, suggesting that the judicial branch has played a limited role in interpreting the Constitution because of its tenet of judicial restraint. As a result, the government has filled the interpretive gap without resort to formal amendment of the Constitution. Finally, Section F discusses constitutional scholars' claims as to when constitutional amendment is desirable based on a cost-benefit analysis. Combined with post-war politics, the structure of the Constitution, and judicial restraint, the cost-benefit analysis contributes to the constitutional stability without widespread popular support.

\section{B. The conventional explanation of the constitutional stability}

\section{Dichotomous constitutional amendment debate in japan}

Conventionally, in Japan debates on Constitutional amendment have been occupied by two extreme positions: Goken-ha and Kaiken-ha. Generally speaking, Goken-ha are anti-revisionist groups, they try to prevent any Constitutional amendment. Kaiken-ha are pro-revisionist groups, those who try to amend every Constitutional provision. Behind these extreme attitudes is the idea that a little leak will sink a great ship. The ship is Article 9. This clause provides that Japan "forever renounce[s] war as a sovereign right of the nation" and that "land, sea, and air forces, as well as other war potential, will never be maintained." ${ }^{6}$ On the one hand, Goken-ha have thought that for the sake of preventing revision of the peace clause of Article 9, any constitutional amendment should not be allowed because it would become a little leak of a great ship. On the other hand, Kaiken-ha believes that for the sake of accomplishing the revision of Article 9, change is needed to accustom people to constitutional amendments. This experience would be a little leak of a great ship. ${ }^{7}$ Because of this background, "[u]nder the Japanese Constitution, 'constitutional amendments' fall into the context of being fundamental amendments or being completely refused or

\footnotetext{
${ }^{6}$ Nihonkoku Kenpō [The Constitution of JaPAn], art. 9.

${ }^{7}$ Where do their attitudes toward the Constitution come from? An American commentator, Jed Rubenfeld explores this issue. Rubenfeld emphasizes that for a constitution to take root, there is a need for the populace to feel a national commitment to the history and narrative of a self-given constitution, enacted by the people themselves. If the constitution has not been democratically enacted, there will always be doubts about its legitimacy, which will prevent it from becoming rooted firmly. Rubenfeld cites Japan as a typical example of it. See Jed Rubenfeld, Freedom And Time: A Theory Of Constitutional SELF-GOVERnMENT 13 (2001). It is true that Goken-ha's claims of an "imposed constitution" has some weak points, but the issue to be addressed here is the social fact that this argument, for all its theoretical, factual, and practical weaknesses, is gaining a certain level of support. Yasuhiro Okudaira stated that " $[\mathrm{w}] \mathrm{e}$ can suppose that there are considerable numbers of people in Japan saying 'This imposed constitution needs immediate revision!'-and not all of them are members of the LDP. One should not overlook this reality. Yasuhiro Okudaira, 'Jishu Kenpō Seitei=Zenmen Kaisei' Sōhihan [A General Critique of 'Independently Enacting a Constitution = Full Constitutional Reform'], 840 SEKAI 117, 119 (2013).
} 
obstructed. It is regrettable that work cannot be done on individual items which genuinely need amending (revising) for advancing the Japanese Constitution." 8

Politically, the right-wing, conservative parties such as the LDP have been Kaiken-ha. The LDP asserted revision of the Constitution as its party platform since the beginning of the party. The left-wing, progressive parties such as the Japanese Socialist Party (JSP) and the Japanese Communist Party (JCP) have been Goken-ha. They oppose LDP's attempts to change the Constitution, notwithstanding its contents. ${ }^{9}$ Many constitutional scholars in Japan have also been categorized as Goken-ha by newspapers and other media, and they are sometimes self-professed Goken-ha. ${ }^{10}$

The media have magnified this dichotomous attitude toward the Constitution. In Japan, almost all forms of major media have regularly conducted opinion polls concerning the Constitution with questions such as, "do you think a revision of the Constitution of Japan is needed?" It is interesting to note how broadly the question is phrased because it does not indicate what amendment or which provision. ${ }^{11}$ This general questionnaire has been continuously used since the $1950 \mathrm{~s} .{ }^{12}$ It is evidence of the pervasive, dichotomous attitude towards the Constitution in Japan.

\section{Anti-revisionists' account for stability}

Goken-ha and Kaiken-ha have proposed different reasons for the stability of the Japanese Constitution. It is well-known that the Goken-ha made a statement claiming that the reason for the stability is the Japanese people's profound endorsement of the Constitution and its philosophy. For example, the Japanese Communist party-one of the most powerful proponents of the Constitution-currently claims in the AKAHATA [Red Flag] - a national daily newspaper - that "the reason why the people do not expect the revision of the Constitution is not that they are conservative. Instead, the contents of the Constitution is so great that people need not feel any amendments."13 Many constitutional scholars emphasize that Japanese people endorsed the "imposed constitution" 14 soon after its enactment, as evidence of that claim. ${ }^{15}$ They tend to use a public opinion poll conducted by the daily Mainichi Shimbun-published on May 5, 1946-as the basis of their assertion. ${ }^{16}$ It found that eighty-five percent of respondents supported a new Tennō [emperor] system of a draft to the Constitution of Japan which situated the Tennō as a symbol of Japan (thirteen percent of the respondent oppose), seventy percent of respondents said that a war-renouncing article was necessary (twenty-eighty percent of the respondents said it was

\footnotetext{
${ }^{8}$ Kōjl Satō, Rikken-Syugi Ni Tsuite: Seiritsu Katei To Gendai [On Constitutionalism: Formation Process and THE MODERN AGE] 225 (Sayu-sha, 2015).

${ }^{9}$ It should be noted that at the time of the Constitutional enactment, one of the leaders of Communist Party, Sanzō Nosaka, strongly opposed the introduction of the peace clause of Article 9 because it undermined the independence of the Japanese race. The Communist Party was not Goken-ha, but an anti-U.S. party. In 1994, this party officially adopted Goken-ha position.

${ }^{10}$ In 1969, one of the monthly law magazines "Hōritsu Jihō" conducted a questionnaire survey to public law scholars. It showed that seventy percent of respondents said the SDF was unconstitutional. See generally 41 Hōritsu Jihō 54 (1969). The same type of survey conducted by them in 1981 also showed about eighty percent of the respondents thought the SDF was unconstitutional. See generally 53 Hōritsu Jihō 59 (1981).

${ }^{11}$ Yasuo Hasebe, Kenpō Toha Nanika [What is a Constitution?] 126-28 (Iwanami-syoten, 2006).

${ }^{12}$ Shirō Sakaiya, Kenpō To Yoron: Sengo Nihonjin Ha Kenpō To Dou Mukiatte Kitanoka [Constitution and Public Opinion: How Japanese People Confront the Constitution After War] 52-53, 86-87. (Chikuma-syobō, 2017).

${ }^{13}$ The Crucial Year to Admit No Abe's Constitutional Revision, DAIlY AKAHATA, Jan. 4, 2018, http://www.jcp.or.jp/akahata/ aik17/2018-01-04/2018010402_01_1.html

${ }^{14}$ The Japanese Constitution is usually regarded as imposed. See, e.g., Frederick Schauer, On the Migration of Constitutional Ideas, 37 CONN. L. REv. 907, 907-18 (2005). See also supra note 7.

${ }^{15}$ See David S. Law, The Myth of the Imposed Constitution, in Social and Political Foundations of Constitutions 239, 252-59 (Denis Galligan \& Mila Versteeg, eds., 2013).

${ }^{16}$ Miyoko Tsujimura, Kenpō Kaisei Ron No Shōten: Heiwa, Jinken, Kazoku Wo Kangaeru [The Focus Point of the Arguments of Constitutional Amendment: Thinking About Peace, Human Rights, and Family] 16 (HōrituBunka-sya, 2018); see also Law, supra note15, at 254.
} 
unnecessary), and sixty-five percent said they supported the rights and duties of the people (thirty-three percent of the respondents sought revision). ${ }^{17}$ Since the enactment of the current Constitution, the Japanese people have cherished it and have not desired its amendment. ${ }^{18}$

Such an explanation does not seem to reflect real public opinion, however. Shirō Sakaiya-a professor of political science at Tokyo Metropolitan University-recently published a book titled "Constitution and Public Opinion." 19 He indicates that the poll of 1946 did not reflect actual demographic composition at that time because that poll was only reflected the views of the "intellectual classes." 20 Thirty-nine percent of the total 2,000 respondents were university graduates, twenty-four percent were public servants, thirteen percent were women, and only six percent were farmers. ${ }^{21}$ In his book, Sakaiya comprehensively collects the results of more than 1,200 public opinion polls performed in the postwar period (1945-2016) and clarifies how the general public saw the Constitution. Based on his thorough research, Sakaiya concludes as follows:

To get straight to the bottom line, Japanese people did not consider the Constitution of Japan as absolutely perfect at the beginning of its enactment, and since then it has never been thought that it was inviolable to this day.... It can be said that Japanese people have cast a skeptical eye toward the Constitution of Japan at all times. The biggest reason for never realizing any constitutional amendments is, as pointed out well, the constitutional restriction of the amendment on Article 96. For successive LDP governments, the condition to the amendment proposal that required a concurring vote of two-thirds or more of all the members of each House has been too big a hurdle to overcome. ${ }^{22}$

\section{Pro-revisionists' account for stability}

Is the strict amendment procedure the reason for Japanese Constitution's stability? It is true that the JSP - which belonged to the Goken-ha-held one-third of the Diet and therefore could prevent presentation of a draft amendment in the system of 1955, in which two primary left and right parties confronted each other. It is also well-known that the Kaiken-ha frequently makes statements claiming that the reason for the invariability of the Constitution is the excessive strictness of constitutional amendment procedure as set out in Article 96. Article 96 provides as follows:

1. Amendments to this Constitution shall be initiated by the Diet, through a concurring vote of two-thirds or more of all the members of each House and shall thereupon be submitted to the people for ratification, which shall require the affirmative vote of a majority of all votes cast thereon, at a special referendum or at such election as the Diet shall specify.

2. Amendments when so ratified shall immediately be promulgated by the Emperor in the name of the people, as an integral part of this Constitution.

\footnotetext{
${ }^{17}$ The Response of the People, Daily Mainichi Shimbun, May 27, 1946.

${ }^{18}$ NaOki Kobayashi, Nihon Ni OKeru Kenpō -Dōtai No Bunseki [An Analysis to Constitutional Dynamics in JAPAN] 59 (Iwanami-syoten, 1963); Mark A. Chinen, Article 9 of the Constitution of Japan and the Use of Procedural and Substantive Heuristics for Consensus, 27 MiCH. J. INT'L L. 55, 93 (2005).

${ }^{19}$ SAKAIYA, supra note 12 .

${ }^{20} I d$. at 65 .

${ }^{21} I d$. at $64-66$.

${ }^{22} I d$. at 290, 292-93. Sakaiya also said at the Japan National Press Club on December 19, 2017, "In short, a key message of my book is that people haven't seen the Constitution as something so 'sacred' that it should not be touched in the postwar years." Reiji Yoshida, Scholar Plumbs Postwar Polls to Challenge Japanese Constitution 'Myths', JAPAN TIMES (Jan. 7, 2018), https://www.japantimes.co.jp/news/2018/01/07/national/scholar-plumbs-late-20th-century-polls-gauge-publics-inclinationsrevising-japans-constitution/\#.XGCBj89KjOQ.
} 
Pro-revisionists have criticized the initial threshold of the constitutional amendment procedure as too high to allow the proposal of any amendments to the people. For instance, when Shinzo Abe became Prime Minister for the second time in December 2012, he showed great interest in revising of the Constitutional amendment procedure. He argued that the current amendment procedure stipulated in Article 96 was too strict to adapt to changing international and domestic environments, and that it deprived the sovereign people of their right to amend the Constitution. ${ }^{23} \mathrm{He}$ suggested relaxing the threshold for a draft amendment proposal from a two-thirds majority of all the members of each House to a simple majority of all the members of each House. ${ }^{24}$ His proposal retained the mandatory national referendum. ${ }^{25}$

The threshold requirement in the Japanese Constitution is not so uncommonly high as to prevent any amendment. For example, using the legislature's vote threshold requirement as the primary factor, political scientist Arend Lijphart measured the difficulty of amending the constitution in 36 democratic countries. ${ }^{26}$ Lijphart reduced a great variety of constitutional provisions into four basic types: Supermajorities greater than two-thirds, two-thirds majorities, between two-thirds and ordinary majorities, and ordinary majorities. Using this index, Lijphart placed Japan in the highest rigidity category, but six other countries-Argentina, Korea, Australia, Switzerland, Canada, and United States-which have implemented many constitutional amendments were put in the same category. ${ }^{27}$

Studies that used different scales to measure a country's difficulty of amending its constitution do not categorize the Japanese Constitution as the most rigid constitution. In his classic work on the difficulties of the amendment process, Donald Lutz ranked the U.S. Constitution as the most rigid one, and the Japanese Constitution as tenth of thirty-two countries. ${ }^{28}$ This research suggests that the Japanese Constitutional amendment process is not so strict as prohibit any amendment.

It is true that the difficulty of acquiring a two-thirds majority in each house depends heavily on the electoral system. But it is enough here to point out that the procedures for amending the constitution are not the only factors that determine the difficulty of constitutional amendments.

\section{Shortcomings of political debates on constitutional amendments}

For the reasons discussed above, both sides' accounts of the stability of the Japanese Constitution flawed. Masami Itō, former Supreme Court Justice and law professor at Tokyo University, made the following statement in his book:

\footnotetext{
${ }^{23}$ The LDP's official guidebook to their proposed draft amendment to the Constitution explains the reason why they think a change to amendment procedure necessary. It states that because every constitutional amendment has to be directly judged by the sovereign people's will in a referendum, the strict threshold requirement before submission narrows down the opportunity of expressing sovereign people's will, and it results in the current constitution not reflecting the sovereign people's will. The Liberal Democratic Party, Nihonkoku kenpō sōan QઐA [QঊA on the Draft of the Japanese Constitution] (Enlarged ed., Oct. 2013) at 36, https://jimin.ncss.nifty.com/pdf/pamphlet/kenpou_qa.pdf.

${ }^{24}$ As a matter of course, the majority of all the members of each House is not the same as the majority of those members present. Although the former requirement is harder than the latter, many critics of prime minister Shinzō Abe and his ruling party have argued that his proposal for the amendment procedure makes it as flexible as an ordinary statute. Nevertheless, an ordinary statute can be enacted by a majority of each House present and without a mandatory referendum. Therefore, such criticism is fatally inaccurate. Legal philosopher Shigeru Otsuka criticizes this as a deceptive argument motivated by political or ideological reasons, not by academical ones. See Shigeru Otsuka, Kenpō Kaisei Genkai Ron No Ideology Sei [The Ideological Nature of the Discussion of Limiting Constitutional Amendment] 2-40 (Seibundō, 2017).

${ }^{25}$ Prime Minister Abe ceased his efforts to change the amendment procedure because of intense criticism. On the problem of amending the constitutional amendment rule in Japan, see Richard Albert, Amending Constitutional Amendment Rules, 13 INT'L J. CONST. L. 655 (2015).

${ }^{26}$ Arend Lijphart, Patterns of Democracy: Government Forms And Performance in Thirty-Six Democracies, 206-07 (2d ed. 2012).

${ }^{27} I d$. at 211 .

${ }^{28}$ Donald Lutz, Toward a Theory of Constitutional Amendment, 88(2) AM. PoL. SCI. Rev. 355, 355-70 (1994).
} 
The difficulty [of amending the constitution] is due to other factors rather than procedural issues. The regulations in the constitution are determined by a variety of factors whether detailed or simple, what sort of standard the people and government believe the constitution to be, whether reality and the constitution are strictly separate because of political and social changes, what people think about the role of constitutional interpretation to fill in the gaps, and whether there is sufficient political capital to realize an amendment. Therefore, the difficulty of amending the constitution needs to be determined from a vast number of angles. ${ }^{29}$

\section{Amendment cultures}

A noteworthy study concerning this point was conducted by Tom Ginsburg and James Melton, who attempted to demonstrate the relationship between "amendment difficulty" and "amendment rate." ${ }^{30}$ According to Ginsburg and Melton, many of the traditional studies that attempt to quantify amendment difficulty have focused on the rate of constitutional amendments and the various formal procedural factors for changing the constitution, such as the number of actors involved and how many votes are required. Analysis that has explored these various factors and the actual rate of constitutional amendments have only demonstrated a fragile relationship, however. It has been noted that studies that measure the difficulty of constitutional amendments is stressful in and of itself. ${ }^{31}$ Therefore, Ginsburg and Melton posited the hypothesis that amendment culture rather than the difficulty of the formal amendment procedure is the decisive factor in the difficulty of amending a constitution. In their article, amendment culture is defined as "the set of attitudes about the desirability of amendment, independent of the substantive issue under consideration and the degree of pressure for change." ${ }^{2}$ The results of Ginsburg and Melton's analysis using the variables rate of constitutional amendments and amendment culture-because this cannot be easily measured, it was substituted for the frequent replacements of the body of the constitution in the concerned country-showed that these are the best predictors. They concluded that the procedural rigidity for amending a constitution is not the primary factor in the rate of constitutional amendment. ${ }^{33}$

Ginsburg and Melton's study backs up the previous points noted by Masami Itō. Itō espoused the necessity of a discussion conducted from a vast number of angles, and this could be looked at as pointing out the need for further investigation of the factors that regulate the "amendment culture" in Japan.

\section{The pathology of amendment cultures}

Some theories characterize a certain attitude about constitutional amendments as a type of pathology. So, what type of amendment culture is considered pathological? What about Japanese dichotomous attitudes toward the Constitution?

The American Constitutional scholar Kathleen Sullivan uses the words "Constitutional Amendment Fever" ${ }^{34}$ or "Amendmentitis." ${ }^{35}$ to describe the phenomenon of increases in proposed constitutional amendments-stipulations for a balanced budget, for term limits, and for

\footnotetext{
${ }^{29}$ Masami Itō, Kenpō [The Constitutional Law] 18-19 (Kōbun-dō, 3d ed. 1995).

${ }^{30}$ Tom Ginsburg \& James Melton, Does the Constitutional Amendment Rule Matter at All? Amendment Cultures and the Challenges of Measuring Amendment Difficulty, 13 InT'L J. CONST. L. 686 (2015).

${ }^{31} I d$. at $692-98$.

${ }^{32} \mathrm{Id}$. at 699.

${ }^{33} \mathrm{Id}$. at $709-12$.

${ }^{34}$ See Kathleen M. Sullivan, Constitutional Constancy: Why Congress should Cure Itself of Amendment Fever, 17 CARDOZO L. REV. 691 (1996).

${ }^{35}$ Kathleen M. Sullivan, Constitutional Amendmentitis, 23 The Am. Prospect, no. 23, Fall 1995, at 20.
} 
authorizing Congress and the states to prohibit flag desecration-in America following the 1994 presidential election. Sullivan wrote:

This rash of amendment proposals is cause for alarm, even apart from any of their individual merits. For there are strong structural reasons for amending the Constitution only reluctantly and as a last resort. This strong presumption against constitutional amendment has been a bedrock in our constitutional history, and there is no good reason for overturning it now. ${ }^{36}$

The structural reasons that Sullivan brings up are stability, rule of law, coherence, generality, and the role of the courts. She goes into more depth on each of these points. First, there is no need to tamper with a constitution that has stood the test of time without failing. Second, the constitution — which has a higher priority than the ordinary statutes—will become like ordinary statutes if it is frequently changed. It is essential to prevent the resulting situation whereby the areas of law and politics are too intermingled. Third, it is possible that the coherency and consistency of the entire constitution will be lost because of a hasty constitutional amendment. Fourth, it could damage the generality of constitutional regulations. Fifth, in America, the courts have a flexible interpretation of the law, so very frequent formal constitutional amendments are not needed. Further, frequent constitutional amendments-particularly amendments intended to overturn court interpretations of the constitution - could potentially undermine the legitimacy of the courts that set out these interpretations. ${ }^{37}$

Vicki Jackson has recently posited some objections to Sullivan's argument. ${ }^{38}$ Jackson argues that in the U.S. there is a theoretical and political discourse that emphasizes the extreme difficulty of amending the Constitution through the formal process provided by Article V of the U.S. Constitution. ${ }^{39}$ Jackson pointed out the argument that the Constitutional amendment should be a last resort, as Sullivan's did, has created a political culture in which it is very difficult actually to amend the Constitution. ${ }^{40}$ Jackson continues her analysis by stating that one consequence of this sort of political culture is that it encourages a tendency to depend on a work-around methodology. In the case of America, the apparent alternative form of amendments to the constitution comes through court decisions on constitutional issues. ${ }^{41}$ Jackson identifies issues with this route because it overlooks the importance of consent of the citizens, which should be the primary element that guarantees the legitimacy of the Constitution. Jackson wrote that "over-reliance on interpretation and change in the judiciary as the sole methods for constitutional change undervalues the significance of more active forms of public consent for constitutional legitimacy; too strong a convention against formal textual amendment saps the democratic legitimacy of the formal text." ${ }^{2}$ Jackson then points out the significance of clearly written constitutional amendments to change constitutional precedents set forth by the courts. Her concerns about "amendophobia" - namely the pathology of being irrationally afraid of employing a constitutional amendment even when it is appropriate ${ }^{43}$ — are set out much like Sullivan in her discourse on amendment fever.

\footnotetext{
${ }^{36}$ Sullivan, supra note34, at 694.

${ }^{37} I d$. at $695-703$.

${ }^{38}$ See Vicki C. Jackson, The (Myth of Un) Amendability of the US Constitution and the Democratic component of Constitutionalism, 13 INT'L J. CONST. L. 575 (2015).

${ }^{39}$ For a study that is consistent with Jackson, see SANFORD LEVINSON, OUR UNDEMOCRATIC CONSTITUTION: WHERE THE Constitution Goes Wrong (And How We The People Can Correct It) (2008). Chapter 6 of this book is particularly useful for reference. Incidentally, Levinson criticizes Sullivan who is critical of constitutional amendments in general. Id. at 176.

${ }^{40}$ Jackson, supra note38, at 584.

${ }^{41} I d$. at 604 .

${ }^{42} I d$. at 576 .

${ }^{43} I d$. at 602 .
} 


\section{Diagnosis of Japanese debates}

The main points of these two opposing arguments involve the evaluations of making changes to a constitutional system without formal amendments to a constitution, and-more specificallyhow to evaluate changes to a constitutional system via the courts. Sullivan assesses this as a positive point and states it as a reason why constitutional amendments should not be made. Conversely, Jackson is uncomfortable with the assumption that the courts are the main actors for making changes to a constitutional system.

Let us return to Japan. Sullivan does not refer to any specific proposals for constitutional amendments in her argument, but she emphasizes it as a general argument. ${ }^{44}$ Jackson's argument is also developed in the context of America, but she states that other countries could have a similar situation with regard to this problem, so it should not be emphasized as an argument that only applies to America. ${ }^{45}$ Their arguments seem to be a valuable reference when considering the Japanese situation. On the one hand, Kaiken-ha looks like it has been infected by an Amendments fever. On the other hand, Goken-ha looks like it has been infected by an Amendophobia. Not only are their accounts of constitutional stability inadequate but so also are their attitudes to the Constitution. Unfortunately, the Goken-ha and Kaiken-ha have formulated the Japanese people's perception of the Constitution.

\section{How do Japanese people see the constitution?}

Section B explored the traditional dichotomous attitudes toward the Constitution in Japan and the failure of their accounts of constitutional stability. Section $\mathrm{C}$ argued that to understand the reason for the constitutional stability, we need to view it from multiple angles and focus on the amendment cultures. So, what constitutes Japanese amendment culture? In Section D, we further explore how Goken-ha and Kaiken-ha have made Japanese amendment culture somewhat pathological. Then I shall argue that the political debate between them affects ordinary people's view of the Constitution.

\section{Interpretation of article 9}

Goken-ha and Kaiken-ha have endorsed a sharply different interpretation of Article 9. Soon after the enactment of the Constitution of Japan in 1946, the international environment radically changed: The increased tension between the U.S. and the U.S.S.R., the emergence of the communist countries such as China and North Korea, and the outbreak of the Korean War in 1950. Japan created Keisatsu Yobi-Tai (National Police Reserve) in 1951, Hoan-Tai (National Security Force) in 1952, and Jiei-Tai (Self Defense Forces (SDF)) in 1954, notwithstanding the pacifist clause of Article 9. It reads as follow:

1. Aspiring sincerely to an international peace based on justice and order, the Japanese people forever renounce war as a sovereign right of the nation and the threat or use of force as a means of settling international disputes.

2. In order to accomplish the aim of the preceding paragraph, land, sea and air forces, as well as other war potential, will never be maintained. The right of belligerency of the state will not be recognized.

This clause appears to prohibit an organization such as the SDF. So how has the government interpreted this clause in order to legalize the existence of the SDF? The government has

\footnotetext{
${ }^{44}$ Sullivan, supra note 34 , at 704 .

${ }^{45}$ Jackson, supra note36, at 605.
} 
developed a somewhat unique interpretation of Article $9 .{ }^{46}$ It is true that the language of Article 9 of the Constitution appears to prohibit "use of force" in all forms in international relations, but when considered in light of "the right to live in peace" as recognized in the Preamble of the Constitution and the "rights to life, liberty, and the pursuit of happiness" as guaranteed in the article 13 of the Constitution, ${ }^{47}$ Article 9 of the Constitution should not be interpreted to prohibit Japan from taking measures of self-defense necessary to maintain its peace and security and to ensure its survival. ${ }^{48}$ Therefore, although Article 9 paragraph 2 prohibits the maintenance of "land, sea and air forces, as well as other war potential," Japan is permitted to possess the minimum necessary level of self-defense capabilities, and that is not categorized as "war potential." The SDF is constitutional because it is within those limits and used purely for self-defense. Furthermore, the United States' forces in Japan-provided for in the Treaty of Mutual Cooperation and Security between Japan and the United States of America (the Japan-US Security Treaty) - which was concluded simultaneously with the Treaty of Peace with Japan on September 8, 1951-is not included in "war potential" under Article 9. ${ }^{49}$

The left-wing parties and the majority of constitutional scholarship have criticized this governmental interpretation of Article 9 as Kaishaku-Kaiken (constitutional amendment through interpretation, without formal amendments). They argue that even if Article 9 does not prohibit Japan from taking measures of self-defense necessary to maintain its peace and security and to ensure its survival, it does prohibit any Senryoku (war potential). Japan must exercise the right of self-defense-not through a quasi-military force such as SDF-through the police or citizens themselves. ${ }^{50}$

\section{Postwar politics: An overview}

Post-War politics has proceeded based on the government's interpretation of Article 9. In the 1950s, after Japan regained its sovereign status, conservative parties (the LDP was established in 1955) argued for formal constitutional revision based on the recognition of the imposed constitution. Many hawkish politicians, such as Ichirō Hatoyama and Nobusuke Kishi-who became prime minister-claimed that there was a discrepancy between the actual constitutional system and the text of Article 9, and that the Constitution should be revised to correct this discrepancy. The JSP also recognized the difference between reality and ideal, but they argued for the abolition of the SDF and the Japan-US Security Treaty in order to adjust the reality to the ideal.

Following the struggle and the aftermath of the conflict over the Japan-U.S. Security Treaty in 1959-1960, the LDP stopped loudly arguing for constitutional amendment and tried to preserve the status quo until 1990: The coexistence of the SDF, the Japan-U.S. Treaty, and Article 9. Such a pragmatic approach had been approved not only by the voters - who had made the LDP the ruling party since then-but also by the media and the judiciary, even if passively.

In the 1990s, the discrepancy became deeper because of the change in international politics. During the Gulf War, 1990-1991, many countries provided troops as part of a multinational force. Japan was also requested to send the SDF to join the multinational forces but could not accept the request due to Article 9 of the Constitution. Instead of sending the SDF, Japan contributed about

\footnotetext{
46"Relationship between the Right of Collective Self-Defense and the Constitution" submitted by the Government to the Committee on Audit of the House of Councilors on October 14, 1972.

${ }^{47} \mathrm{See}$ Nihonkoku KenPō [The CONSTitution of JAPAN], art. 13 (stating that "[a]ll of the people shall be respected as individuals. Their right to life, liberty, and the pursuit of happiness shall, to the extent that it does not interfere with the public welfare, be the supreme consideration in legislation and in other governmental affairs").

${ }^{48}$ See generally Masahiro SaKata, Seifu No Kenpō Kaisyaku [Governmental InTERPRETAtion of the Constitution] (Yuhikaku, 2013). The author is the former Director General of Cabinet Legislation Bureau, see infra Section E.III.

${ }^{49}$ Supreme Court, grand bench, December 16, 1959, Keishu Vol.13, No.13, 3225 (Sunagawa Case).

${ }^{50}$ See, e.g., Nobuyoshi Ashibe, Kenpō [Constitutional Law], 61 (Iwanami-Shoten, 6th ed. 2015).
} 
thirteen billion dollars to help fund the military operation, but this did not earn international respect. This Gulf War trauma led to Japan enacting an Act on Cooperation with United Nations Peacekeeping Operations and Other Operations ${ }^{51}$ (PKO Act) to "enable active contributions by Japan to international peace efforts centering upon the United Nations." 52 Since then, Japan has dispatched the SDF for foreign peacekeeping operations many times. ${ }^{53}$

In 1994, the leader of the JSP-Tomiichi Murayama-became Prime Minister in a coalition formed with the LDP. Although the JSP held the tenet of abolishing the SDF and repealing the Japan-U.S. Security Treaty due to their unconstitutionality, Murayama suddenly changed their longstanding policy and confirmed the status quo. ${ }^{54}$ At that time, many parties formed mainly by former LDP members sprung up like mushrooms after the rain. These parties also approved the constitutionality of the SDF, the Japan-U.S. Security Treaty, and dispatching the SDF abroad for PKO activities.

In the 2000s, the LDP government led by Junichirō Koizumi enacted the Anti-Terrorism Special Measures $\mathrm{Law}^{55}$ allowing for the dispatch of the SDF to the oil-fueling missions in the Indian Ocean. ${ }^{56}$ The first administration of Koizumi's successor, Shinzo Abe, started to suggest a possible right of collective self-defense under the war-renouncing Constitution. In 2009, the Democratic Party of Japan (DPJ) won a landslide victory at the general election of the House of Representatives on August 30, 2009, forming the government in place of the LDP. The DPJ also approved the constitutionality of the SDF and considered the possibility of the right of collective self-defense under the war-renouncing Constitution. ${ }^{57}$

On June 1, 2014, the Cabinet led by second administration of Shinzō Abe re-interpreted Article 9 to permit exercising part of the right of collective self-defense that had been prohibited by previous interpretation. The Cabinet decision stated as follows:

Under such recognition and as a result of careful examination in light of the current security environment, the Government has reached a conclusion that not only when an armed attack against Japan occurs but also when an armed attack against a foreign country that is in a close relationship with Japan occurs and as a result threatens Japan's survival and poses a clear danger to fundamentally overturn people's right to life, liberty and pursuit of happiness,

\footnotetext{
${ }^{51}$ Act No. 79 of June 19, 1992. The following principles have been arranged to ensure that participation in Peacekeeping Operations is in accordance with Article 9 of the Constitution. (1) Agreement on a cease-fire shall have been reached among the parties to armed conflicts; (2) Consent for the undertaking of UN Peacekeeping Operations as well as Japan's participation in such operations shall have been obtained from the host countries as well as the parties to armed conflicts; (3) The operations shall strictly maintain impartiality, not favoring any of the parties to armed conflicts; and (4) Should any of the requirements in the above-mentioned principles cease to be satisfied, the Government of Japan may withdraw Self-Defense Force (SDF) contingent. (5) The use of weapons shall be limited to the minimum necessary to protect the lives of personnel, etc. See Ministry of Foreign Affairs of Japan (MOFA), Japan's Contribution to UN Peacekeeping Operations (PKO): Outline of Japan's International Peace Cooperation (May 14, 2015), https://www.mofa.go.jp/fp/ipc/page22e_000683.html.

${ }^{52}$ Act on Cooperation for United Nations Peacekeeping Operations and Other Operations, art. 1, http://www.pko.go.jp/ pko_j/data/law/pdf/law_e.pdf.

${ }^{53}$ See MOFA, supra note 51.

${ }^{54}$ Shüginn Kaigiroku [House Of Representative Plenary Session Minutes], 130th Diet Session, No. 2, 5 (July 20 , 1994). It should be noted that the Social Democratic Party (SDP), which is renamed the JSP, declared that the existence of the SDF violates the Constitution in 2006. The JSP had been biggest opposition party once, but now the SDP has lost public support and only has four seats in the Diet (two in the House of Representatives and two in the House of Councilors). Such a rapid decline is the reason for this party's inconsistent attitude toward Article 9 and SDF. Junji Annen, Nihonkoku- Kenpō no Igi to Unei [Value and Operation of the Constitution of Japan], in Yasuo Hasebe Ed., Iwanami-KōZa KenPō 6: KenPō To JikAn [Iwnami Course of Lecture on Constitution No.6: Constitution AND Time] 136 (Iwanami-syoten, 2007).

${ }^{55}$ Act No. 113 of November 2, 2001 (expired on November 1, 2007).

${ }^{56}$ See Katsumi Ishizuka, Japan's Policy Towards the War on Terror in Afghanistan (Afrasian Research Centre, Ryukoku University, Working Paper No. 3, 2012), http://afrasia.ryukoku.ac.jp/english/publication/upfile/WP003.pdf.

${ }^{57}$ See Makoto Arai, Seiken- Kōtai to Seiji-Syudō no Kenpō-Kaisyaku [Change of Government and Constitutional Interpretation let by Government], 34(3) Hiroshima HōGAKU 53 (2011).
} 
and when there are no other appropriate means available to repel the attack and ensure Japan's survival and protect its people, use of force to the minimum extent necessary should be interpreted to be permitted under the Constitution as measures for self-defense in accordance with the basic logic of the Government's view to date. ${ }^{58}$

Many opposing parties and constitutional scholars severely criticized this change of constitutional interpretation as a "crisis of constitutionalism" or "destruction of constitutionalism." tested by standing at the front of the National Diet and requested Abe's resignation day after day. In spite of that event, the LDP-led by Abe and its junior coalition party New Komeito-won overwhelming victories in three successive national elections: The general election of the House of Representatives on December 14, 2014, the ordinary election of the House of Councilors on July 10, 2016, and the lower house election on October 22, 2017. Now Prime Minister Shinzō Abe's ruling coalition retains its two-thirds parliamentary majority in both houses, and it has sufficient numbers for proposing constitutional amendments, for the first time since the enactment of the Constitution.

\section{Formation of people's attitude toward the constitution}

In such a manner, post-war politics have gradually come to regard the constitutionality of the SDF as self-evident, postponing resolution of the discrepancy between the ideal and the reality concerning the Article 9 by formal constitutional amendment. So, it is natural for Japanese people to think the difference between the constitutional text and the existence of the SDF is not that big a deal. Today, even if the text of the Constitution is unchanged, the vast majority of citizens have approved the constitutionality of SDF, including its activity abroad.

Interestingly, a current opinion poll shows that about fifty percent of respondents think Abe's attempt to change the interpretation of the Constitution is unconstitutional, but simultaneously a majority of respondents responded negatively to the question, "Do you think laws based on that interpretation should be abolished?" This result indicates that ordinary people do not seem to think the state of unconstitutionality should be solved as soon as possible. ${ }^{60}$ Japanese people have come to the conclusion that the constitutional text need not reflect the reality, and that it can be flexibly interpreted by the government. Due to the post-war politics mentioned above, the Japanese Constitution has gradually lost its normative force among people. This is one aspect of constitutional culture in Japan and is thought to be the reason for constitutional stability in the negative sense.

\section{E. The structural characteristics of the constitution of Japan}

One of the other factors that enables such political balance in post-war Japan is the structure of the Constitution. To think about the constitutional structure, we should distinguish two different issues, detail and scope. ${ }^{61}$ Detail refers to the depth in which the constitution treats the topics

\footnotetext{
${ }^{58}$ Cabinet Decision on Development of Seamless Security Legislation to Ensure Japan's Survival and Protect its People, Ministry of Foreign Affairs of Japan (June 1, 2014), https://www.mofa.go.jp/fp/nsp/page23e_000273.html.

${ }^{59}$ See generally Noboru Yanase, Debates Over Constitutionalism in Recent Japanese Constitutional Scholarship, 19(2) Soc. SCI. JAPAN J. 193 (2016). Compare Yasuo Hasebe, The End of Constitutional Pacifism? 26(1) WASH. INT'L L.J. 125 (2016), with Hajime Yamamoto, Interpretation of the Pacifist Article of the Constitution by the Bureau of Cabinet Legislation: A New Source of Constitutional Law? 26 PAC. RiM L. \& POL'Y J. 99 (2017).

${ }^{60}$ Shirō Sakaiya, Nihon-Jin no Kenpō Ishiki [Japanese people's Understanding of the Constitution], 90 HŌRITSU JIHŌ 131 (2018).

${ }^{61}$ Tom Ginsburg, Constitutional Specificity, Unwritten Understandings and Constitutional Agreement, in CONSTITUTIONAL Topography: Values And Constitutions 77 (Andras Sajó \& Renata Utiz eds., 2010).
} 
within its scope, and scope refers to what issues are included in the constitution. ${ }^{62}$ As discussed below, the governmental structure provided in the Japanese Constitution is brief and narrow, which could make people even less motivated to amend the Constitution.

\section{Compact constitution}

It has been said that the Japanese Constitution is a compact one. ${ }^{63}$ But, that claim seems to be grounded not on a close comparative examination of world constitutions, but rather on a comparison with a limited number of optimally selected constitutions. Kenneth McElwain and Christian Winkler clarify the Japanese Constitution's structural characteristics using largenumber statistical methods. Based on their statistical survey, McElwain and Winkler analyzed the reasons that Japan's Constitution has endured without being changed even once. ${ }^{64}$

According to McElwain and Winkler, one of the reasons that Japan's Constitution has not been amended is that it is quite short when compared with the constitutions of other countries. ${ }^{65}$ The median value for the number of words (translated in English) in constitutions examined for this paper was 13,630 words. Japan's Constitution has only 4,986 words, which ranks fifth to last of the 190 constitutions studied. ${ }^{66}$ Compared with other democratic countries such as the United States (7,762 words), Germany (27,379 words), France (10,180 words), Italy (11,708 words), and Canada $\left(19,565\right.$ words), the small number of words in Japan's constitution is striking. ${ }^{67}$ Generally speaking, most provisions of the Japanese Constitution are characterized as vague standards, not as concrete rules. It means that interpretation has a primary role in relation to constitutional meaning.

Moreover, the Japanese Constitution does not treat broad topics. According to McElwain and Winkler, among ninety-two common issues that have been specified in many constitutions' texts, the Japanese Constitution addresses approximately thirty-four percent of these topics. ${ }^{68}$ Thus, the areas and topics that can be addressed by the ordinary laws are extensive. ${ }^{69}$ Moreover, the Japanese Constitution frequently uses such phrases as "provided (for) by law" (fourteen times), "fixed by law" (seven times), "determined by law" (four times), "in accordance with law" (four times), "established by law" (three times); that is, "[i]n effect, many issues enumerated in other constitutions are either unaddressed or left explicitly to ordinary law in Japan, giving more room to the Diet and the courts to fill in the gaps via statutes and case law." ${ }^{\prime 70}$

Japan has a tradition of concise constitutions. When Japan was preparing the draft of the Constitution of The Empire of Japan-the so-called Meiji Constitution, which went into effect on November 29, 1890-one of the primary instructions given by Hirofumi Itō, the first Prime Minister, was that "the constitution should leave it only in a general outline about the emperor state politics, use the concise, clear text, and make it elastic to adapt to

\footnotetext{
${ }^{62} I d$. at 78,81 .

${ }^{63}$ See, e.g., Makoto Ōishi, Tōchi-Kikō Eno Tenbō [Prospects of Framework of The Government] 7, 38-39 (Yuhikaku, 2008).

${ }^{64}$ Kenneth Mori McElwain \& Christian G. Winkler, What's Unique About the Japanese Constitution?: A Comparative and Historical Analysis, 41 J. JAPANESE STUD. 249 (2015); see also Kenneth Mori McElwain, Nihonkoku Kenpō No Tokui Na Kōzō Ga Kaiken Wo Hituyō To Shinakatta [The Japanese Constitution's Unique Structure Makes Constitutional Revision Unnecessary], 131 CHUŌ-KŌRON 76 (2017).

${ }^{65}$ See also Takeshi Inoue, The Constitution of Japan and Constitutional Reform, 23 (2) AsIA-PAC. REV. 1, 9-11 (2016).

${ }^{66}$ Constitution Rankings, supra note 4 . Smaller constitutions than Japan are in ascending order, Monaco (3,814 words), Iceland (4,089 words), Laos (4,820 words), Latvia (4,917 words).

${ }^{67}$ Moreover, the current trend of the constitutional writing is towards longer and more detailed constitutions. See Mila Versteeg \& Emily Zackin, Constitutions Un-entrenched: Toward an Alternative Theory of Constitutional Design, 110 AM. Pol. SCI. Rev. 657 (2016).

${ }^{68}$ McElwain \& Winkler, supra note64, at 261.

${ }^{69} I d$. at $260-62$.

${ }^{70} \mathrm{Id}$. at 262.
} 
future progress." ${ }^{71}$ When drafting the current Constitution, Tastukichi Minobe, who was then the most influential constitutional scholar, claimed there was no need to revise the Meiji Constitution for the sake of the democratization of Japan. He wrote that democratization of the Meiji Constitution could be achieved without formal amendment through revision and repeal of laws and effective management. ${ }^{72}$

\section{Structural reform without formal constitutional amendment}

Because of this structural characteristic of the Constitution, the Japanese "Constitutional Order," which is comprised of "not only various stipulations incorporated into the text of the Constitution, but also judicial precedents and constitutional cases with a force almost equivalent to the Constitution, and regular ordinances subordinate to them and Kenpō-fuzoku hō [constitutional acts or statutes],"73 is largely comprised of materials other than the constitutional text itself. Especially in the realm of governance structure, constitutional acts play a pivotal role. ${ }^{74}$ Constitutional acts are defined as those that "are not formally incorporated into the text of the Constitution but are rather entrusted in parliamentary statutes and other ordinances"; but these laws are "equally foundational for the organization and management of national governance." 75 It can be said that the concept of constitutional acts has almost the same meaning to "small-c constitution," which "consists of the body of rules, practices, and understanding, written or unwritten that actually determines who hold what kind of power, under what conditions, and subject to what limits."76

Under these backgrounds, many drastic governance structural reforms have been carried out in Japan since the 1990s as a result of changes in constitutional acts, not the Constitution itself. The following reforms resulted from changes of the constitutional act and not from those in the actual Constitution.

In 1994, the National Diet amended the "Public Offices Election Act"77 several times to realize a party-oriented and policy-oriented electoral system. It changed the electoral system of the House of Representatives from a multiple-seat constituency system - from which three to five candidates are elected-to the electoral system combining single-seat constituencies with proportional representation. In some countries, these election system reforms must be accomplished through a constitutional amendment. ${ }^{78}$ The Japanese Supreme Court upheld the constitutionality of the new election system, saying:

There is no single, invariable model for the election system .... Since the Diet is empowered to decide which system of election is appropriate for achieving the goal of electing fair and effective representatives for both houses by its discretion, when the Diet has adopted a new system of election, it is unconstitutional only when the choice of the actual system is beyond the discretion of the Diet, even considering its broad discretionary power, because it exceeds

\footnotetext{
${ }^{71}$ Kentarō Kaneko, Kenpō Seitei To Ōbeijin No Hyōron [Constitutional Making and Critiques of Westerners] 133 (Nihon-Seinenkan, 1937).

${ }^{72}$ Tatsukichi Minobe, The Problems of Constitutional Amendment, vol. 1, AsAHI SHIMBun (Oct. 20, 1945).

${ }^{73}$ ŌIsHI, supra note63, at 6; see also Richard Albert, Quasi-Constitutional Amendments, 65 Buffalo L. Rev. 739 (2015).

${ }^{74} I d$. at 10 .

${ }^{75} I d$. at 35 .

${ }^{76}$ David S. Law, Constitutions, in The Oxford Handbook of EMPIRICAl Legal Research 376, 377 (Peter Cane \& Herbert M. Kritzer eds. 2010); see also Ernest A. Young, The Constitution Outside the Constitution, 117 Yale L.J. 408 (2007)

${ }^{77}$ Act No. 2 of February 4, 1994, Act No. 10 of March 11, 1994; Act No. 104 of November 25, 1994.

${ }^{78}$ For example, Ireland, which has a similar amendment procedure to Japan, amended its Constitution many times to change the election system. See Michael Gallagher, Politics, the Constitution and the Judiciary, in POLITICS IN THE REPUBLIC OF IRELAND, 63-66, 380-81 (John Coakley \& Michael Gallagher eds., 6th ed. 2018).
} 
the limits mentioned above, or it is against the requirement of equality under the law and therefore, against the requirements of the Constitution. ${ }^{79}$

At the same time, the National Diet enacted the Political Party Subsidies Act ${ }^{80}$ to institutionalize a party subsidy system. Although the Japanese Constitution itself does not say anything about political parties, they have been assigned a leading role in the constitutional system by ordinary statute.

In the executive branch, Gyōsei Kaikaku Kaigi (the Administrative Reform Council) was established in 1996 and produced its final report in $1997 .{ }^{81}$ The Report declared that its basic idea and objective was to restructure Kono-Kuni no Katachi (the shape of our country), which phrase has been used interchangeably with Constitutional order in Japan. As this phrase indicates, the Administrative Reform aimed to change the Japanese Constitutional order. The Report recommended: (1) Reinforcing Cabinet functions, (2) restructuring central government ministries and agencies, (3) cutting back government functions and promoting privatization, and (4) reforming the public service system. Based on the recommendation, the Diet amended the Cabinet Act, ${ }^{82}$ and enacted many laws such as the Basic Act on Central Government Reform. ${ }^{83}$

In 2000, to strengthen the regional governance and management as well as the promotion of decentralization reform, the Omnibus Decentralization $\mathrm{Act}^{84}$ and other related acts radically reformulated the local government system. This changed the hierarchical relationship between the central and local governments to an equal and cooperative one. It abolished the system in which the central government delegated some of its authorities to the local governments, treating them as organs of the central government within a scope of delegated authority. It promoted the devolution of authority, from central to prefectural, from prefectural to municipal, and so on. Since then, local government reform has been ongoing.

Concerning the Judiciary, many reforms have resulted in the introduction of a lay judge system (Saiban-in system) which allows the participation of citizens in criminal trials, ${ }^{85}$ the establishment of graduate law schools to increase the number of legal professionals, the establishment of an Intellectual Property High Court, and others. These have been introduced based on the Opinion Paper of the Judicial System Reform Council (JSRC). ${ }^{86}$ The Opinion Paper, Judicial System Supporting Japan in the $21^{\text {st }}$ Century, ${ }^{87}$ published on June 12, 2001, proposed wholesale reform of the current Japanese legal and judicial system. It begins as follows:

Japan, which is facing difficult conditions, has been working on various reforms, including political reform, administrative reform, promotion of decentralization, and reforms of the economic structure such as deregulation. What commonly underlies these reforms is the will that each and every person will break out of the consciousness of being a governed object and will become a governing subject, with autonomy and bearing social responsibility, and that the people will participate in building a free and fair society in mutual cooperation and will

\footnotetext{
${ }^{79}$ Saikō Saibansho [Supreme Court] Nov. 10, 1999, 53 Minshu 1704.

${ }^{80}$ Act No. 5 of February 4, 1994.

${ }^{81}$ Gyōsei Kaikaku Kaigi, Saisyū-Hōkoku [Final Report of the Administrative Reform Council] (December 3, 1997). English executive summary version is available at https://japan.kantei.go.jp/971228finalreport.html.

${ }^{82}$ Act No. 5 of January 16, 1947.

${ }^{83}$ Act No. 103 of June 12, 1998.

${ }^{84}$ Act No. 87 of July 16, 1999.

${ }^{85}$ See Noboru Yanase, Deliberative Democracy and the Japanese Saiban-in (Lay Judge) Trial System, 3 (2) ASIAN J.L. \& SOC'Y, 327 (2016).

${ }^{86}$ JSRC was established under the Cabinet in July 1999, Article 2, Paragraph 1 of the Law concerning Establishment of the Justice System Reform Council, Act No. 68 of June 9, 1999.

${ }^{87}$ JSRC, Recommendations of the Justice System Reform Council: For a Justice System to Support Japan in the $21^{\text {st }}$ Century (June 12, 2001), https://japan.kantei.go.jp/judiciary/2001/0612report.html.
} 
work to restore rich creativity and vitality to this country. This reform of the justice system aims to tie these various reforms together organically under "the rule of law" that is one of the fundamental concepts on which the Constitution is based. Justice system reform should be positioned as the "final linchpin" of a series of various reforms concerning restructuring of "the shape of our country." 88

As mentioned above, the phrase "the shape of our country" is the translation of "Kono Kuni no Katachi." The Opinion Paper situated the series of reforms as a practically constitutional amendment through constitutional acts, not through formal amendment procedure. ${ }^{89}$

In sum, as Takeshi Inoue claims, "the fact that the Japanese constitution has not been amended once since its enactment indicates that it has the flexibility to handle the changing circumstances of society without being revised. Conversely, however, it also shows the possibility that it is a weak standard for limiting power." ${ }^{\text {"S }}$ Sakaiya also pointed out that the government has coped with new situations through reinterpretation of the constitutional text and revision of the constitutional acts, and states that this is one reason for the Constitution's stability. ${ }^{91}$

\section{Judicial restraint}

As discussed above, the concise Japanese Constitution leaves much room for interpretation. But what organization should have the task of interpreting the textual meaning of the Constitution? Rosalind Dixon argues that constitutions are generally either framework style constitutions that only regulate policies in extremely general language, or codified constitutions that formally document more detailed or restrictive regulations. Dixon explains that framework style constitutions are founded on faith in the courts and their capacity for interpretation and fair decision-making. Conversely, codified constitutions are designed as a system that assumes distrust in entities to make accurate interpretations and decisions based on a constitution. Dixon recommended that anyone trying to establish a new democratic body of constitutional law should design their constitution keeping these concepts in mind. ${ }^{92}$

The Japanese Constitution is to be classified as a typical framework style constitution with a judicial review system imported from the United States. ${ }^{93}$ As discussed above, the concise Japanese Constitution leaves much room for interpretation. Therefore, it appears on its face that the task of interpreting the textual meaning of the Constitution would fall to the judicial branch. Yet, since the judicial review system's beginning in $1947,{ }^{94}$ the Supreme Court of Japan has been widely regarded as reluctant to use that power. Up until now, there have only been ten cases in which the Supreme Court has struck down statutes as unconstitutional. ${ }^{95}$ Many academics have researched

\footnotetext{
${ }^{88}$ Id. at ch. 1.

${ }^{89}$ Satoshi Machidori, Seiji-Gaku kara Mita "Kenpō-Kaisei” [ "Constitutional Amendment" from the point of view of Political Science], in "Kenpō-Kaisei" No Hikaku Seiji-Gaku [Comparative Political Science on "Constitutional AmENDmEnT"] 2, 15 (Keigo Komamura and Satoshi Machidori eds. 2016); see also ŌisHi, supra note63, at ii.

${ }^{90}$ Takeshi Inoue, Nihon Koku Kenpō to Rikken Syugi: Nani o Kangaeru Bekika [Japanese constitutional law and constitutionalism: What should we think?] 86 (5) HōrITSU JIHŌ 12, 18-19 (2014).

${ }^{91}$ SAKAIYA, supra note12, at 293.

${ }^{92}$ Rosalind Dixon, Constitutional Drafting and Distrust, 13 INT'L J. Const. L. 819, 824-25 (2015).

${ }^{93}$ Saikō Saibansho [Supreme Court] Oct. 8, 1952, 6 Minshu 783 (Japan) declared that "Our courts cannot exercise a power whereby, in the absence of such a concrete legal dispute" and "the Supreme Court possesses the power to review the constitutionality of laws, orders, and the like, but that authority may be exercised only within the limits of judicial power; in this respect, the Supreme Court is no different from the lower courts."

${ }^{94}$ See Norikazu Kawagishi, The Birth of Judicial Review in Japan, 5 InT'L J. Const. L. 308 (2007).

${ }^{95}$ Saikō Saibansho [Supreme Court], Apr. 4, 1973, 27 Keishu 265 (parricide case); Saikō Saibansho [Supreme Court] Apr. 30, 1975, 29 Minshu 572 (Pharmaceutical Affairs Law case); Saikō Saibansho [Supreme Court] Apr. 14, 1976, 30 Minshu 223 (malapportionment of electoral districts at house of Representatives case); Saikō Saibansho [Supreme Court] July 17, 1985, 39 Minshu 1100 (malapportionment of electoral districts at house of Councilors case); Saikō Saibansho [Supreme Court]
} 
the reasons for the judicial passivity of the Supreme Court of Japan, ${ }^{96}$ but for this article it suffices to note that all agree that judicial review has not played a critical role in Japan's politics. As a result of the judicial restraint, the government might be the primary agent that interprets the Constitution. ${ }^{97}$

Many academics have pointed out that the Cabinet Legislation Bureau (CLB), which is established under the Cabinet, ${ }^{98}$ has effectively exercised the power of constitutional review. CLB examines the constitutionality of all legislative bills that will be submitted from the Cabinet to the Diet. CLB also gives legal opinions to the Cabinet members as well as to the Cabinet as a whole. Moreover, the CLB Directors General and other officials have been invited to the Diet or its committee meetings and answered legal and constitutional questions. The interpretation of Article 9 mentioned in Section B.I. is also the work of the CLB.

In short, the government of Japan can introduce essential change without resorting to constitutional amendments due to the structure of the Constitution and extreme judicial restraint. ${ }^{99}$ It means that a government that has received a majority of the vote can change the shape of the country. In other words, the Japanese Constitution can be interpreted in democratic or populistic ways. This relationship between the Constitution and populism is one feature of Japanese constitutional culture. ${ }^{100}$

Apr. 22, 1982, 41 Minshu 408 (The Forest Law case); Saikō Saibansho [Supreme Court] Sept. 11, 2002, 56 Minshu, 1439 (The Postal Law case); Saikō Saibansho [Supreme Court] Sept. 14, 2005, 59 Minshu 2087 (seeking declaration of illegality of deprivation of the right to vote of Japanese citizens residing abroad); Saikō Saibansho [Supreme Court] June 4, 2008,62 Minshu 1367 (Nationality Law case); Saikō Saibansho [Supreme Court] Sept. 4, 2013, 67bMinshu 1320 (Discrimination on children born out of wedlock case); Saikō Saibansho [Supreme Court] Dec. 10, 2015, 69 Minshu 2427 (noting the prohibition of remarriage to woman case).

${ }^{96}$ See, e.g., Yasuo Hasebe, The Supreme Court of Japan: Its Adjudication on Electoral Systems and Economic Freedoms, 5 InT'L J. Const. L. 296 (2007); David S. Law, The Anatomy of a Conservative Court: Judicial Review in Japan, 87 TEX. L. REV. 1545 (2009); Shigenori Matsui, Why Is the Japanese Supreme Court So Conservative?, 88 WASH. U. L. REV. 1375 (2011); David S. Law, Decision Making on the Japanese Supreme Court: The Politics of Supreme Court Adjudication: Why Has Judicial Review Failed in Japan? 88 WAsH. U. L. Rev. 1425 (2011); John O. Haley, Constitutional Adjudication in Japan: Context, Structures, and Values, 88 WASH. U. L. REV. 1467 (2011); Tokujin Matsudaira, Judicialization of Politics and the Japanese Supreme Court, 88 WASH. U. L. Rev. 1559 (2011); Koji Tonami, Judicial Review in Japan and its Problems, 33 WASEDA BulL. CoMP. L. 10 (2015).

${ }^{97}$ The Supreme Court explicitly entrusted the interpretation of the Constitution to the Cabinet, the Diet, and the people on the topics of "an act of a government of high political nature." In the So-called Sunagawa Case (Saiko Saibansho [Supreme Court] Dec. 16, 1959, 13 Keishu 3225), the Supreme Court stated as follows:

\begin{abstract}
An act of a government of high political nature, having direct relationship to the sovereign act of the state, is beyond the province of judicial review, even if it results in a legal dispute and even if it is legally possible to render judicial determination as to its validity or invalidity. It must be admitted that such determination should be entrusted to such a political department like the Government or the Diet, which owes a political responsibility to the people, with whom rests the sovereign power of the state, and ultimately to the political decision of the people themselves. This limitation imposed upon the judicial power, in its final analysis, is derived from the principle of separation of three powers: Although there is no express provision in the Constitution to this effect, it must be interpreted that such is the design inherent in the Constitution because of the very nature of the thing, when viewed in the light of the highly political nature of the act of the government now under consideration, the nature of the court as a judicial organ of the state, and the procedural limitation which inevitably accompanies the trial.
\end{abstract}

In this case and the Japanese type of "political question doctrine," see Po Liang Chen and Jordan T. Wada, Can the Japanese Supreme Court Overcome the Political Question Hurdles? 26 PAC. RIM L. \& POL'Y J. 349 (2017).

${ }^{98}$ Act No. 252 of July 31, 1952.

${ }^{99}$ See Satoshi Yokodaido, Kenpō-ten no Kaisei to Kenpō-Chitsujyo Hendō no Syosō [Amendments to the Constitutional Text and Various Aspects of Changes in the Constitutional Order] 28 Kenpō Mondai [Constitutional Problems] 7, 8-11 (2017); Satoshi Yokodaido, Kenpō no Architecture: Kenpō o Seido-Sekkei Suru, [Architecture of Constitutions: Designing Constitutions], in Architecture To Hō: Hōgaku No Architectural Na Tenkai? [Architecture And law: Architectural Turn On The Jurisprudence?] 199, 209-13 (Yō Matsuo ed., Kōbun-dō, 2017).

${ }^{100}$ It would be characterized as one of "abusive constitutionalism," using the informal method of constitutional change by interpretation. See David Landau, Abusive Constitutionalism, 47 U.C. DAVIS L. REV. 189, 195 (2013). In this Article, my argument is that this method of constitutional change is the product of Japanese constitutional cultures. 


\section{F. What is the desirable attitude toward constitutional amendment?}

As discussed in the previous Section, the structure of the Constitution of Japan allows for a wide range of interpretation. The ordinary laws enacted by the Diet and the government-not the judicial branch-have taken the responsibility of constitutional construction or interpretation. Is this a desirable situation? How do constitutional scholars evaluate this? In this Section, we shall consider constitutional scholars' arguments that try to judge whether it is appropriate to make amendments based on the costs and the benefits. These amplify a negative attitude toward constitutional amendments in general.

\section{Cost-benefit analysis}

Many scholars have sought to evaluate whether it is desirable to amend the Constitution on the basis of cost-benefit analysis. For example, political scientist Atsushi Sugita, who is the member of "Save Constitutional Democracy Japan"101 — a group critical of the Abe administration-pointed out that "from the objective of Constitutionalism, the topics that can be addressed by ordinary statutes should be managed with ordinary statutes, not with the Constitution. The Constitution should only be involved when the topics cannot be addressed by general statutes." 102 Therefore, "using a Constitutional amendment on a matter that can be solved by ordinary statutes is a waste of time and effort." ${ }^{103}$ Similarly, constitutional scholar Yasuo Hasebe's argument about whether the right to privacy or environmental rights should be written in the constitution, also uses costsbenefits analysis. Hasebe wrote:

$[\mathrm{M}]$ erely writing these things into the text of the constitution without solidifying implementation through statutes in the National Diet or precedents set by the courts would be meaningless. The right to privacy has already been solidified by the court's interpretation of Article 13 of the Constitution. As it is, if this right is infringed upon, a person can seek damages or an injunction against the violator. It seems like nothing would be gained by making a new constitutional amendment for what citizens already have. Environmental rights are meaningless without laws that make them concrete, and if there is a law that makes it concrete, then a constitutional amendment has only a symbolic meaning. ${ }^{104}$

These are the typical sort of arguments given about costs and benefits.

Nonetheless, as mentioned in Section D-because almost every political reform can be achieved through ordinary statutes due to the structure of the Constitution-if the advisability of amendment is assessed based on costs and benefits, it is almost always assessed as being inadvisable. If so, is it an appropriate way of judging the desirability of constitutional amendments?

\section{Constitutional change always evaluated negatively}

Hasebe invokes David Strauss' article entitled “The Irrelevance of Constitutional Amendments"105 as a basis of his argument. ${ }^{106}$ Strauss argues that in a "mature democratic society" formal

\footnotetext{
${ }^{101}$ Save Congressional Democracy Japan 2014 (2014), http://constitutionaldemocracyjapan.tumblr.com/setsuritsushyushi.

${ }^{102}$ Atsushi Sugita, Mattō na Kenpō Kaisei Rongi no Jyōken [Proper Conditions for Arguments about Constitutional Amendments, in Abe-Ryu Kaiken Ni No O! [Say No to Abe's Style of Constitutional Reform!] 207 (Yoichi Higuchi \& Jiro Yamaguchi eds., Iwanami-syoten, 2015).

${ }^{103} I d$.

${ }^{104}$ HASEBE, supra note11, at 18-19.

${ }^{105}$ David A. Strauss, The Irrelevance of Constitutional Amendments, 114 HARV. L. Rev. 1457 (2001).

${ }^{106}$ HASEBE, supra note11, at 129-31.
} 
constitutional amendments are not the main or even an essential means of changing the constitutional system:

There is great appeal to the idea that the written Constitution is the authentic voice of the People on matters of fundamental principle. But however true this idea was for the original Constitution and its early amendments, it presents a misleading picture of the constitutional development of the mature Republic. The fundamental changes in the constitutional order have occurred by means other than the amendment process. They have occurred without amendments, despite the rejection of amendments, or in ways that made amendments only incidentally important. ${ }^{107}$

Strauss is discussing the U.S., but since it is presented as a statement that is valid for mature democracies, it is a valuable reference when considering the general phenomenon of constitutional amendments.

Constitutional scholarship uses cost-benefit analysis to evaluate negatively almost all of the constitutional amendments proposed by the LDP and others. Currently, the party is arguing for four specific amendments: (1) Clarifying the legal status of the SDF under the Constitution, (2) making education free of charge, (3) giving the government emergency powers in case of a natural disasters and national crisis, and(4) eliminating House of Councilors' electoral districts that merged two prefectures with one district, ${ }^{108}$ correcting the state of unconstitutionality that followed from the Supreme Court's decision that there was a vote-value disparity, ${ }^{109}$ maintaining that at least one person can be elected from each prefecture. ${ }^{110}$ Those who oppose these amendment proposals argue that almost all of them do not necessarily require the formal constitutional amendment. First, because the SDF is already constitutional under the official interpretation of the Constitution, ${ }^{111}$ writing it down expressly in the Constitutional text is futility, waste of time and money. Second, making education free of charge can be achieved through enacting general statutes; resorting to a constitutional amendment is pointless. ${ }^{112}$ Third, introduction of an

\footnotetext{
${ }^{107} I d$. at $1504-05$. Strauss attempts to deny the relationship between changes in the constitutional system and constitutional amendment. His reasoning for this is that (1) there are examples of changes to the constitutional system without there being formal constitutional amendments, (2) there are examples of cases when even if a proposed formal constitutional amendment is not adopted, there is a change in the constitutional foundations that make it seem as though it has been, and (3) even if a formal constitutional amendment is made, there are examples of it not playing a significant role in changing the constitutional system. In addition, he attempts to substantiate the validity of his own statement, and with regard to his third point, he brings up (a) examples where in reality there has already been a change to the constitutional system, and a constitutional amendment was passed just to solidify these changes, (b) examples where the constitutional system is not changed through a constitutional amendment, and it takes a long time actually to change the constitutional system, and (c) examples of a constitutional amendment being nothing more than a means to determine an adjustment issue rather than being revisions that make a change to the constitutional system. Id. at 1469-89.

${ }^{108}$ Shimane and Tottori, Ehime and Tokushima prefectures are merged into single constituencies by the Act No. 60 of August 5, 2015.

${ }^{109}$ Judgement of the Supreme Court on 2012 (Saikō Saibansho [Supreme Court] Oct. 17, 2012, 66 Minshu Vol. 66, 3357) held that to meet the requirement of equality in the value of votes while maintaining the current mechanism designed to use a prefecture as a unit of constituency had become extremely difficult, and that inequality should be eliminated as soon as possible through legislative measures such as making a reasonable change to the current system of setting the number of seats for each prefecture-based constituency because the prefecture-based constituency was not a constitutional requirement. Saikō Saibansho [Supreme Court] Nov. 26, 2014, 68 Minshu 1363 follows it.

${ }^{110}$ LDP to focus on four areas in crafting Constitution Amendment Proposal, Kyodo News, June 6, 2017.

${ }^{111}$ See Sections D.I-II.

${ }^{112}$ See, e.g, Ritsu Nakagawa, Kyōiku no Musyō-ka ha Kenpō Kaisei ni Yotte Jitugen Sarerubeki mono nano ka [Should Education free of charge be realized through the Constitutional Amendment?], in KENPŌ KAISEI WO YOKU KANGAERU [Taking Constitution Seriously] 121, 122-25 (Shōjirō Sakaguchi et al. ed., Nihon-Hyōron-sya, 2018).
} 
emergency clause to the Constitution is more or less complicated. ${ }^{113}$ If this proposal is to authorize an extension of legislators' terms in response to major earthquakes and other disasters, it would not be necessary as Article 54 Section 2 of the Constitution already allows for such a situation. ${ }^{114}$ If this proposal is to concentrate powers in the hands of the prime minister to tackle the emergency situation effectively, it would risk the perpetuation of emergency power. ${ }^{115}$ Accordingly, such an emergency clause should not be introduced into the Constitution. ${ }^{116}$ Fourth, eliminating the House of Councilors' merging of electoral districts could be realized through the introduction of an indirect election system and putting the house of Councilors as representatives of the region. ${ }^{117}$ In such a way, almost every proposal for a constitutional amendment is assessed by the cost-benefit analysis and diagnosed as unnecessary.

\section{Other reasons for constitutional amendment}

The stance of this constitutional scholarship might be the reason for the Japanese people's attitude toward the Constitution.

First, as discussed above, the majority of constitutional scholars had thought the SDF was unconstitutional. ${ }^{118}$ Nevertheless, when they criticized Abe's interpretative change of Article 9, their claim was based on the former interpretation of the government, which they had attacked. In other words-because the vast majority of people already approve and admit the existence of the SDF-constitutional scholarships seeks to refrain from their fundamental assertion of its unconstitutionality. Instead, it only criticized the change of interpretation from what the government had been saying previously. Nevertheless, many people view their claim as motivated not by jurisprudential reasons, but by political reasons. ${ }^{119}$ Second, although there are many scholars explicitly acknowledging the constitutionality of the SDF among critics of Abe's administration,

\footnotetext{
${ }^{113}$ LDP constitutional panel discusses 'emergency clause,' including limit on private rights, DAILY MAINICHI SHIMBUN, Mar. 8 , 2018.

${ }^{114}$ It reads "When the House of Representatives is dissolved, the House of Councilors is closed at the same time. However, the Cabinet may in time of national emergency convoke the House of Councilors in emergency session." Because the term of office of members of the House of Councilors is six years, and election for half the members shall take place every three years (art. $46 \mathrm{sec}$. 2), at least half of the members of the House of Councilors are always in office. Measures taken at that emergency session are provisional and become null and void unless agreed to by the House of Representatives within ten days after the opening of the next session of the Diet (art. $46 \mathrm{sec}$. 3).

${ }^{115}$ See generally Bruce Ackerman, Before The NeXt Attack: Preserving Civil Liberties In An Age Of Terrorism (2007).

${ }^{116}$ The latter reason is not based on cost-benefit analysis. See Aikyō Kōji, Kaiken-Mondai to site no Kinkyū-Jitai Jyōkō [Emergency Clause as the Problem of Constitutional Amendment], 15 RonKYü-JURIST 193 (2015).

${ }^{117}$ Katsutoshi Takami, "Zen-Kokumin no Daihyō" to "Chihō no Fu" ["representative of all the people" and "Local Government”], in Sengo Nihon Kenpōgaku 70Nen No Kiseki [The Path Of The Japanese Constitutional Academics For Seventy Years After War] 51 (Hōritsu Jihō Editorial Department ed., Nihon-Hyōron-sya, 2018); It is noteworthy that on the topics of malapportionment of electoral districts to the House of Councilors, Takami resorts to the radical change of constitutional interpretation despite the Supreme Court's decisions mentioned at supra note109. On the other hand, Takami has severely criticized the change of constitutional interpretation of the government concerning the Article 9 as a violation of constitutionalism. For him, the former is permissible, and the latter is unforgivable under the Constitution, but the reason why has not been cleared. See also Kōsuke Okumura, Tōchi-Kikō Kaikaku [Political Reform of the System of Government], supra note112, at 151, 152-61.

${ }^{118}$ See supra note10. In 2015, the Asahi Shimbun conducted a questionnaire survey to constitutional law scholars. It showed about sixty-three percent of respondent said the SDF is unconstitutional or possibly unconstitutional. As these data shows, some commentators say "constitutional studies of resistance" that focus on "effectively limiting authority and its theoretical structures" are overwhelming on the one hand, "constitutional studies of construction" that "have the perspective of taking power as our own and establishing structures and methodologies to express it" are weak. See KAZUYUKI TAKAHASHI, GENDAIRikkensyugi No Seido-Kōsō [Institutional Ideas In Modern Constitutionalism] 15 (Yuhikaku, 2006).

${ }^{119}$ These groups of scholars do not support a constitutional amendment that would realize their objective: Expressly in the text guarantee unarmed neutrality or absolute pacifism. This attitude also contributes to their claim to be seen as political.
} 
their attack on Abe's attempt as Kaishaku-Kaiken (constitutional amendment through interpretation, without formal amendment) is also received as a political one. As a philosopher of law, Tatsuo Inoue points out elsewhere, these scholars behave as if they criticize Abe's Kaisyaku-Kaiken simultaneously endorse another type of Kaisyaku-Kaiken. ${ }^{120}$ Such disingenuous behavior contributes to the posture of ordinary Japanese people which is discussed in Section D.III. Third, because many scholars criticize the amendment proposal aimed at eliminating the discrepancy between the actual constitutional order and the text of the Constitution based on the cost-benefit analysis, ordinary people do not find this state of affairs problematic.

The idea of making the constitutional amendment procedure more difficult than passing an ordinary law within the constitutional text-which is universally recognized around the world ${ }^{121}$ —is to reconcile conflicting demands for constitutionalism, those for stability and change. ${ }^{122}$ Under the Japanese Constitution-which has the structural characteristics described in Section D-it is easy for discrepancies between the Constitution and the actual constitutional order to arise. As long as one takes the perspective of championing constitutionalism, amending the Constitution to eliminate a situation where reality appears to contradict the constitutional text should not be dismissed by cost-benefit analysis. ${ }^{123}$

\section{G. Conclusion}

In this Article, I have discussed the reasons for constitutional stability in Japan. The reason is not the popular approval of the Constitution regardless of its origin, but rather cultural reasons. In spite of the dichotomous attitude in political debate toward the Constitution-especially Article 9-the actual post-war politics has proceeded without solving the contradiction between reality and the ideal of Article 9 and the SDF. Such politics have been approved tacitly by the compact Constitution and by judicial restraint on constitutional issues. Also, many constitutional scholars - who have a strong incentive to deter any constitutional amendment—have claimed that the criteria for determining the necessity of constitutional amendment should be evaluated by cost-benefit analysis. It is an analysis of whether the proposed amendment's purpose could be achieved by ordinary laws or change of constitutional interpretation. Due to a mixture of these factors, the Japanese people have gradually lost trust in the normative forces of the Constitution's text and have regarded it as so flexible that it can fit almost any changing environment. That seems to be the reason for constitutional stability in Japan and the characteristics of the relationship between the Constitution and populism in Japan.

\footnotetext{
${ }^{120}$ Tatsuo Inoue, 9-jō Mondai Saisetu: "Sensō no Seigi" and Rikken Minsyusyugi no Kanten kara [Restatement of the Problems with Article 9: From the Perspective of War Justice and Constitutional Democracy], 33 Hō NO RIRON [The Theory of Law] 3 (2015).

${ }^{121}$ About ninety-six percent of world constitutions include amendment provisions. YANIV ROZNAI, UNCONSTITUTIONAL Constitutional Amendments: The Limit of Amendment Powers 22 (2017).

${ }^{122}$ Id. at 4-5. See also AsHiBe, supra note50, at 392.

${ }^{123}$ Some constitutional scholars indicate this point. See Hajime Yamamoto, "Kenpō Kaisei" Mondai no Syosō [Various Aspects of Issues with 'Constitutional Amendments”], 612 Hōgaku seminar 9 (2005); Takeshi Inoue, Rikken Syugi to tekusuto: Nihonkoku Kenpo no Baai [Constitutionalism and Text: In Case of Japan] 20 Q. JURIST 112 (2017). Yokodaido, Kenpō-ten no Kaisei to Kenpō-Chitsujyo Hendō no Syosō, supra note99, at 13-17. Many scholars whose specialty is other than constitution make similar arguments. See, e.g., Yasuaki Ōnuma, Goken-Teki Kaiken-Ron [Arguments for constitutional change to protect the constitutionalism] 1260 JURIST 157 (2004), Takehiro Ōya, Kongen-teki Kiyaku-Syugi wa Kaisyaku-Kaiken o Hōjyu-ka saseruka [Does Radical Conventionalism lets Constitutional Amendment without Formal Procedures unrestrained?], in IWANAMI-KoZA Kenpō 1: Rikken-Syugi No Tetsugaku-Teki Tihei [Iwnami Course Of Lecture On Constitution No.1: Constitution And Time Philosophical Frontier on Constitutionalism] 283 (Tasuo Inoue ed., Iwanami-syoten, 2007), Takehiro Ōya, Kenpō Kaisei Genkai-Ron no Genkai o Megutte [On the Limitations of arguments to limit constitutional amendments], 33 Hō NO RIRON [The Theory of Law] 64 (2015).
} 
Therefore, as I have described, the stability is a product of some sort of pathological phenomenon. My point is, as Versteeg and Zackin pointed out, "constitutional scholars should no longer define constitutional success in terms of the stability (or majesty) of a single constitutional text." 124 Those who want to know the way to stabilize the constitutions should not overestimate Japanese experience nor the normative importance of Article 9 for ordinary Japanese people.

\footnotetext{
${ }^{124}$ Versteeg \& Zackin, supra note67, at 671. See also Junta Okada, Senryō-kenpō no eikyō ni kansuru hikaku-kenkyū josetu: Nihon to Iraku no hikaku o chüshin ni [Introductory Remarks on the Comparative Studies about the Effects of ConstitutionMaking under Occupation], 20(2) HAKUOH HOUGAKU 243 (2014).
}

Cite this article: Yokodaido S (2019). Constitutional stability in japan not due to popular approval. German Law Journal 20 , 263-283. https://doi.org/10.1017/glj.2019.16 